\title{
Carcass characteristics, meat quality and composition of lambs finished in cultivated pastures
}

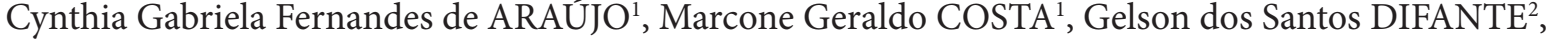 \\ João Virgínio EMERENCIANO NETO ${ }^{1}$, Antonio Leandro Chaves GURGEL ${ }^{2 *}$ (D), Carolina Marques COSTA², \\ Itânia Maria Medeiros de ARAÚJO², Maria Gabriela da Trindade SILVA ${ }^{1}$, Mariana Campelo MEDEIROS ${ }^{1}$
}

\begin{abstract}
Thirty-two Santa Inês male lambs, not castrated, were distributed in a randomized block design to evaluate the effects of different tropical forage cultivars (two Panicum maximum (Syn. Megathyrsus maximus): Aruana and Massai, and two Brachiaria brizantha (Syn. Urochloa brizantha) Marandu and Piatã) on carcass characteristics, quality, physical composition, and meat chemistry. The data were subjected to an analysis of variance, and the means compared using the Tukey test at $5 \%$ significance. There was no effect of cultivars on body weight, slaughter weight, and biometric measurements of the carcass. The Aruana and Piatã cultivars provided higher weights of hot and cold carcasses when compared to the Massai and the Marandu had no significant differences compared to the others. The animals kept in the pasture of the Aruana cultivar showed higher shank yields. However, forage cultivars did not affect the ribeye area or subcutaneous fat thickness. There was also no effect of cultivar on $\mathrm{pH}$, temperature, cooking losses, cooling losses, and meat shear strength. The cultivars did not change the quality and composition of the meat. However, the Aruana, Piatã, and Marandu cultivars were the ones that provided higher carcass weights and ham yields.
\end{abstract}

Keywords: ribeye area; commercial cuts; tropical grasses; sheep; carcass yield.

Practical Application: This research contributes to investigate forage alternatives for sheep meat production in the semiarid region and evaluate the effects of these cultivars on carcass traits and meat composition.

\section{Introduction}

The use of cultivated pastures is a strategy for feeding sheep, as it contributes to a reduction in seasonality and production costs (Emerenciano et al., 2017). In these cultivated systems, grasses of the genera Brachiaria brizantha (Syn. Urochloa brizantha) and Panicum maximum (Syn. Megathyrsus maximus) are predominantly used due to their adaptation to tropical and subtropical climates and high productivity (Gomes et al., 2011; Veras et al., 2020). This can be an alternative for the production of early carcasses with an adequate amount of muscle and good fat deposition. However, the wide variety of cultivars available can show considerable variations in productivity and nutritional value (Emerenciano et al., 2020; Fernandes et al., 2020), all of which can interfere with animal performance and, consequently, the quality of the carcass and meat.

The study of carcass characteristics considers objective and subjective parameters linked to the attributes inherent to the edible portion. Currently, the goal of beef sheep production is to obtain carcasses with a greater amount of muscle and fat levels that are not excessive yet sufficient to guarantee the juiciness and flavor of the meat (Urbano et al., 2017). The main characteristics studied in carcass evaluation are weight, yield, state of greasiness, and conformation (Oliveira et al., 2017; Silva et al., 2018), while the factors that determine carcass quality are genotype, sex, age, rearing system, and health (Ekiz et al., 2012; Hopkins \& Mortimer, 2014; Silva et al., 2020). Another important point to be evaluated in the production of sheep meat is the quality of the meat, which includes the characteristics of color, tenderness, and proximate composition (Santos et al., 2020).

It is known that the different forage grasses show variations in the production and chemical composition of the forage (Veras et al., 2020; Emerenciano et al., 2020; Fernandes et al., 2020 ) and, therefore, we hypothesize that Santa Inês sheep under grazing in different forage cultivars would have altered carcass characteristics, quality and meat composition. The aim of this research is to evaluate the meat quality and carcass characteristics of lambs finished in different forage cultivars of tropical climate during the rainy season.

\section{Material and methods}

The experiment was conducted in accordance with the norms set forth by the Ethics Committee on Animals Use - CEUA/UFRN (approval no. 055/2016). The experiment was conducted in an area of the Research Group in Forage, located at the Academic Unit Specialized in Agricultural Sciences (UFRN), in Macaíba, RN, Brazil (55 $53^{\prime} 35.12^{\prime \prime}$ S, $35^{\circ} 21^{\prime} 47.03^{\prime \prime}$ W, with $160 \mathrm{~m}$ of altitude).

${ }^{1}$ Academic Unit Specializing in Agricultural Science, Universidade Federal do Rio Grande do Norte, Macaíba, RN, Brasil

${ }^{2}$ Faculty of Veterinary Medicine and Animal Science, Universidade Federal de Mato Grosso do Sul, Campo Grande, MS, Brasil

*Corresponding author: antonioleandro09@gmail.com 
The experimental area of 2.88 ha was split into two blocks of 1.44 ha, with four modules of 0.36 ha for each cultivar, which were then subdivided into six paddocks of equal area ( $0.06 \mathrm{ha})$. The evaluation period was from April, the rainy season in the region with an mean monthly rainfall of $164 \mathrm{~mm}$.

The treatments consisted of four tropical grasses: two cultivars of Panicum maximum (Syn. Megathyrsus maximus): Aruana and Massai, and two of Brachiaria brizantha (Syn. Urochloa brizantha): Marandu and Piatã. The pastures were managed under intermittent capacity with a height goal of $50 \mathrm{~cm}$ for pre-grazing. At the post grazing, the height goal was $25 \mathrm{~cm}$ so that approximately $50 \%$ of the available mass could be removed. To ensure the height goals, we used the variable stocking rate according to grass growth and the amount of available forage (Emerenciano et al., 2020).

For the evaluation of animal performance, 32 test sheep were used Santa Inês male lambs, not castrated, all from commercial farms located within the state of Rio Grande do Norte, Brazil. The animals remained on the pasture during the day (from 8 a.m. until 5 p.m.) and were housed in barn with collective pens overnight. Access to water and mineral salt (with monensin) was ad libitum. The mineral supplement had the following composition per $\mathrm{kg}$ of the product): $\mathrm{Na}-147.0 \mathrm{~g}$; Ca-120.0 g; P-87.0 g; S-18.0 g; Zn-3800.0 mg; Fe-18000.0 mg; Mn-1300.0 mg; monensin sodium-1300.0 mg; F-870.0 mg; Cu-590.0 mg; Mo-300.0 mg; I-80.0 mg; Co-40.0 mg; Cr-20.0 mg; Se-15.0 mg. The animals were identified using numbered plastic earrings and necklaces of different colors, one for each cultivar. The animals went through a 15-day adaptation period of grazing and management.

During the pre and post grazing, samples of the pasture were collected to characterize the structure and chemical composition of the cultivars (Table 1). The forage mass, stocking rate and duration of the grazing cycles were determined as described in Emerenciano et al. (2014). Samples of the forage grasses were ground, in triplicates, for further chemical analysis according to the AOAC methodology (Association of Official Analytical Chemists, 2005), to determine the dry matter (DM, method 2001.12), ash (MM, method 942.05), crude protein (CP, method 984.13) and ether extract (EE, method 920.39). The levels of neutral detergent fiber (NDF, method 2002.04), acid detergent fiber (ADF, method 973.18) and lignin (method 973.18) were determined sequentially, using sulfite or thermostable amylase (Association of Official Analytical Chemists, 2005). The in vitro dry matter digestibility (IVDMD) was determined as described by Tilley \& Terry (1963). Calculations of total digestible nutrients were performed according to the equation proposed by Weiss (1999).

The slaughter criterion was weight body weight of animais, so each cultivar had a different grazing period. The Aruana, Marandu, Massai, and Piatã cultivars were grazed for 129, 133, 142 , and 143 days, respectively, until the lambs reached $32 \mathrm{~kg}$ of BW. Upon reaching slaughter weight, the animals' body condition scores (BCS) were evaluated according to Russel et al. (1969). The following biometric measurements were also taken: body length, withers height, rump height, rump width, chest width, and thoracic perimeter. After solid and liquid fasting for 16 hours, the animals were weighed to obtain live weight at slaughter (LWS).

At the time of slaughter, the animals were stunned by trauma to the head in the atlanto-occipital region, followed by exsanguination through the carotid and jugular sections. After skinning and evisceration, the gastrointestinal (GTI) tract. was weighed, full and empty, to determine the weight of the empty body. Then the head (at the atlanto-occipital joint) and extremities (at the metacarpal and metatarsal joints) were removed. The carcasses were weighed to obtain the hot carcass weight (HCW) and hot carcass yield $[\mathrm{HCY}(\%)=\mathrm{HCW} / \mathrm{LWS} \times 100]$, then transferred to a cold room at $5{ }^{\circ} \mathrm{C}$, where they were kept for 24 hours, and finally hung by the tendons on hooks appropriate for maintaining a distance of $17 \mathrm{~cm}$ between the metatarsal tarsal joints.

At the end of this period, the internal temperature, $\mathrm{pH}$, and the following measurements were measured: internal length, chest depth, chest perimeter, croup perimeter, leg length, thigh perimeter, chest width, and croup width (Osório et al., 1999). After cooling, the kidneys, perirenal fat, and tail were removed to obtain the cold carcass weight $(\mathrm{CCW})$. Subsequently, the cooling loss was calculated $[\mathrm{CL}(\%)=\mathrm{HCW}-\mathrm{CCW} / \mathrm{HCW} \times 100]$ and the cold carcass yield was obtained [CCY $(\%)=\mathrm{HCW}-\mathrm{CCW} / \mathrm{LWS} \times 100]$.

Then the carcass was cut in half. The left half was weighed and subdivided into five anatomical regions, and each was weighed individually, according to a methodology adapted from Osório et al. (1999), according to commercial meat cuts: shoulder, neck, loin, leg, and rib. The legs were desiccated for the separation of muscles; bones; and subcutaneous, pelvic, and intermuscular fats, all of which were quantified according to the

Table 1. Pasture characteristics, stocking rate, duration of grazing cycles and chemical composition of the entire plant during the experimental period.

\begin{tabular}{|c|c|c|c|c|}
\hline Variable & Marandu & Piatã & Aruana & Massai \\
\hline $\begin{array}{l}\text { FM in Pre-grazing } \\
\left(\mathrm{kg} \mathrm{ha}^{-1} \mathrm{DM}\right)\end{array}$ & 7075.5 & 5885.3 & 5574.3 & 9728.2 \\
\hline $\begin{array}{l}\text { FM in post-grazing } \\
\left(\mathrm{kg} \mathrm{ha}^{-1} \mathrm{DM}\right)\end{array}$ & 3371.7 & 2736.7 & 3114.0 & 4350.0 \\
\hline Stocking rate $\left(\mathrm{AU} \mathrm{ha}^{-1}\right)^{*}$ & 24.7 & 15.0 & 17.8 & 26.6 \\
\hline $\begin{array}{l}\text { Duration of grazing } \\
\text { cycles (days) }\end{array}$ & 68.7 & 69.9 & 63.8 & 65.3 \\
\hline Dry mater $\left(\mathrm{g} \mathrm{kg}^{-1} \mathrm{NM}\right)$ & 272.3 & 249.1 & 387.9 & 287.2 \\
\hline Ash $\left(\mathrm{g} \mathrm{kg}^{-1} \mathrm{DM}\right)$ & 64.9 & 67.5 & 73.2 & 75.8 \\
\hline $\begin{array}{l}\text { Crude protein } \\
\left(\mathrm{g} \mathrm{kg}^{-1} \mathrm{DM}\right)\end{array}$ & 97.2 & 96.7 & 66.7 & 64.7 \\
\hline Ether extract $\left(\mathrm{g} \mathrm{kg}^{-1} \mathrm{DM}\right)$ & 18.1 & 20.2 & 20.5 & 17.7 \\
\hline $\begin{array}{l}\text { Neutral detergent fiber } \\
\left(\mathrm{g} \mathrm{kg}^{-1} \mathrm{DM}\right)\end{array}$ & 684.1 & 670.9 & 763.1 & 715.1 \\
\hline $\begin{array}{l}\text { Acid detergent fiber } \\
\left(\mathrm{g} \mathrm{kg}^{-1} \mathrm{DM}\right)\end{array}$ & 318.2 & 335.5 & 399.2 & 420.7 \\
\hline Lignin ( g kg$\left.^{-1} \mathrm{DM}\right)$ & 42.4 & 40.8 & 58.4 & 38.2 \\
\hline IVDMD ( $\left.\mathrm{g} \mathrm{kg}^{-1} \mathrm{DM}\right)$ & 643.5 & 624.0 & 575.5 & 603.5 \\
\hline Total digestible nutrients & 588.3 & 594.8 & 542.0 & 570.6 \\
\hline
\end{tabular}

$\left(\mathrm{g} \mathrm{kg}^{-1} \mathrm{DM}\right)$

FM: forage mass; ${ }^{*}$ Animal unit ( $\mathrm{AU}=30 \mathrm{~kg}$ of body weight); NM: natural matter; DM: dry matter; IVDMD: in vitro dry matter digestibility. 
procedure established by Mccutcheon et al. (1993) to determine tissue composition.

In the left half carcasses, a cross section was made between the 12th and 13th ribs to measure the ribeye area in the muscle Longissimus dorsi, on which the outline of the muscle was drawn on a transparent plastic sheet. Two lines were then drawn on the image, where one measured the maximum distance of the muscle in the lateral mean direction (measure A) and the other was perpendicular to the previous one (measure $\mathrm{B}$ ). The calculation of the ribeye area was determined using the formula: $[(\mathrm{A} / 2 \times \mathrm{B} / 2) \times \pi]$, where $\pi=3.1416$. Moreover, in the muscle Longissimus dorsi, with the aid of a digital caliper, the subcutaneous fat thickness was measured between the last thoracic and first lumbar vertebrae.

The loin was dissected and separated from the Longissimus dorsi muscle for carrying out the physico-chemical analyses (color, cooking losses, shear force, and centesimal composition) at the Animal Products Evaluation Laboratory of the Animal Science Department, Center for Agricultural Sciences, Campus II of the Federal University of Paraíba.

To determine the color of the Longissimus dorsi muscle, the Minolta Chroma Meter (model CR-10, MINOLTA ${ }^{\circ}$, Japan) was used, using the CIELAB system, to determine the coordinate indexes: $\mathrm{L}^{*}$ (luminosity), $\mathrm{a}^{*}$ (red index), and $\mathrm{b}^{*}$ (yellow) (Miltenburg et al., 1992). For color evaluation, three readings were obtained for each sample (medial, central, and lateral regions), and the mean of each coordinate was calculated later.

To determine cooking losses, $2.5 \mathrm{~cm}$ thick slices were removed from the Longissimus dorsi muscle, weighed, and roasted on a Fisher ${ }^{\oplus}$ brand (Star model) grill, preheated to $150{ }^{\circ} \mathrm{C}$, until the internal temperature (geometric center of the samples) reached $71^{\circ} \mathrm{C}$, which was measured using a digital thermometer (Delta OHM model HD 9218, Caselle di Selvazzano, Italy). Then the samples were cooled to room temperature and weighed again. Weight losses caused by cooking were calculated using the weight difference of the samples before and after cooking and expressed in percentages.

In the same samples used to determine cooking losses, shear force was determined. Three cylinders were removed from the central part of each sample in the direction of the fiber with the aid of a cylindrical mold of $1.27 \mathrm{~cm}$ in diameter. The shear was performed perpendicularly to the fibers using a TA-XT2 texturometer (Surrey, England) equipped with a Warner Bratzler blade operating at $20 \mathrm{~cm} / \mathrm{min}$, according to the methodology described by Duckett et al. (1998). The peak shear force was recorded, and the results were expressed in $\mathrm{kgf} / \mathrm{cm}^{2}$.

Samples of Longissimus dorsi from each of the 32 animals under study were used to determine the proximate composition of the meat. The muscles were crushed individually in an Arno ${ }^{\circ}$ multiprocessor and placed in semi-rigid plastic containers stored in a freezer at $-18^{\circ} \mathrm{C}$ until use. Analyses of moisture, ash, and protein were performed according to Association of Official Analytical Chemists (2005). Total lipids were determined using extraction in a chloroform-methanol mixture (2:1), followed by evaporation in an oven (TECNAL ${ }^{\circ}$ model TE397/4) operating at $105^{\circ} \mathrm{C} \pm 2{ }^{\circ} \mathrm{C}$ until reaching a constant weight, according to with the methodology described by Folch et al. (1957).

The experimental design was a randomized block, the data were analyzed for variance, and the mean were compared using the Tukey test at $5 \%$ significance. The model used was Yijk $=\mu+F i+B j+\beta(X-X i j)+$ eijk, in which Yijk $=$ observed value of cultivar i in block $\mathrm{j}$ repetition $\mathrm{k} ; \mu=$ general mean effect; $\mathrm{Fi}=$ cultivar effect, $\mathrm{I}=$ Marandu, Aruana, Piatã e Massai; $\mathrm{Bj}=$ block effect; $\mathrm{j}, \mathrm{k}=1,2 ; \beta(\mathrm{X}-\mathrm{Xij})=$ effect of the covariate (final BW) and eijk $=$ random error associated with observation Yijk.

\section{Results}

There was no effect of cultivars $(\mathrm{P}>0.05)$ on body weight, LWS, body length, withers height, rump height, rump width, chest width, chest circumference, and BCS, with mean values and standard errors of $33.69 \pm 0.49 \mathrm{~kg}, 31.68 \pm 0.32 \mathrm{~kg}$, $62.84 \pm 1.07 \mathrm{~cm}, 69.79 \pm 0.98 \mathrm{~cm}, 74.06 \pm 0.98 \mathrm{~cm}, 23.03 \pm 1.18 \mathrm{~cm}$, $17.50 \pm 0.38 \mathrm{~cm}, 92.12 \pm 1.17 \mathrm{~cm}$, and $2.48 \pm 0.14$, respectively. As a result, forage cultivars did not affect the lambs carcass biometric measurements $(P>0.05)$, with mean values and standard errors of $62.87 \pm 1.13 \mathrm{~cm}, 28.19 \pm 0.39 \mathrm{~cm}, 70.34 \pm 0.84 \mathrm{~cm}$, $54.59 \pm 0.94 \mathrm{~cm}, 36.06 \pm 0.72 \mathrm{~cm}, 34.50 \pm 1.24 \mathrm{~cm}, 22.93 \pm 0.75 \mathrm{~cm}$, and $18.28 \pm 0.81 \mathrm{~cm}$ for internal length, chest depth, chest perimeter, croup perimeter, leg length, thigh perimeter, chest width, and carcass croup width, respectively.

Differences were observed between cultivars for empty body weight, with the highest values observed in animals kept in the pastures of Piatã and Aruana cultivars, the lowest values were in animals kept in the pastures of the Massai cultivar, and intermediate values were observed in animals grazed to cultivate Marandu (Table 2). HCW and CCW were higher for animals fed with the Piatã cultivar, lower for those fed with the Massai cultivar, and intermediate for animals fed with Marandu and Aruana cultivars. However, there was no effect of cultivars on HCY, CCY, and gastrointestinal tract content (Table 2).

Neck, loin, and rib weights did not differ between cultivars. However, shoulder and leg weights were higher in the animals kept in the pasture of the Aruana cultivar, lower for animals kept in the pasture of the Massai cultivar, and intermediate values were observed for animals that grazed in the pastures of Marandu and Piatã cultivars. There was no effect of cultivar on the yields of commercial cuts, with the exception of the ham yield, where the highest values were observed in the animals kept in the pasture of the Aruana cultivar, lower for the animals allocated in the pastures of the Piatã and Massai cultivars, and no significant difference for the animals kept in the pasture of the Marandu cultivar (Table 3).

The forage cultivars did not affect $(\mathrm{P}>0.05)$ the ribeye area $\left(13.22 \pm 0.86 \mathrm{~cm}^{2}\right)$ or subcutaneous fat thickness $(0.98 \pm 0.17 \mathrm{~mm})$. There was also no effect $(\mathrm{P}>0.05)$ of the different grasses on the lamb's leg tissue composition, with mean values and standard errors of $23.01 \pm 0.76,69.49 \pm 0.75$, and $4.63 \pm 0.02 \%$ for bone, muscle, and fat percentage, respectively.

The effect of cultivars was not significant for $\mathrm{pH}$, temperature, cooking losses, cooling losses, and shear force. The levels of 
Table 2. Characteristics and mean carcass yields of Santa Inês lambs finished in cultivated pastures.

\begin{tabular}{|c|c|c|c|c|c|c|}
\hline Variables & Marandu & Piatã & Aruana & Massai & SEM & P-value \\
\hline Empty body weight (kg) & $23.78^{\mathrm{ab}}$ & $24.45^{\mathrm{a}}$ & $24.35^{\mathrm{a}}$ & $21.90^{\mathrm{b}}$ & 0.549 & 0.037 \\
\hline Hot carcass weight (kg) & $12.17^{\mathrm{ab}}$ & $12.82^{\mathrm{a}}$ & $12.55^{\mathrm{ab}}$ & $11.40^{\mathrm{b}}$ & 0.311 & 0.012 \\
\hline Cold carcass weight $(\mathrm{kg})$ & $11.69^{\mathrm{ab}}$ & $12.21^{\mathrm{a}}$ & $12.04^{\mathrm{ab}}$ & $10.93^{\mathrm{b}}$ & 0.286 & 0.024 \\
\hline Hot carcass yield (\%) & $38.43^{\mathrm{a}}$ & $39.86^{\mathrm{a}}$ & $38.91^{\mathrm{a}}$ & $37.45^{\mathrm{a}}$ & 0.773 & 0.201 \\
\hline Cold carcass yield (\%) & $36.89^{a}$ & $37.96^{\mathrm{a}}$ & $37.12^{\mathrm{a}}$ & $35.63^{\mathrm{a}}$ & 0.768 & 0.222 \\
\hline GTI content $(\mathrm{kg})$ & $7.89^{\mathrm{a}}$ & $7.72^{\mathrm{a}}$ & $7.89^{\mathrm{a}}$ & $8.51^{\mathrm{a}}$ & 0.482 & 0.325 \\
\hline
\end{tabular}

GTI: gastrointestinal tract; SEM: standard error of the mean. Means followed by different letters on the lines differ statistically using the Tukey test at $5 \%$ probability.

Table 3. Weight and yield of commercial cuts of Santa Inês lambs finished in cultivated pastures.

\begin{tabular}{lcccccc}
\hline Variables & Marandu & Piatã & Aruana & Massai & SEM & P-value \\
\hline $\begin{array}{l}\text { Shoulder } \\
(\mathrm{kg})\end{array}$ & $1.11^{\mathrm{ab}}$ & $1.10^{\mathrm{ab}}$ & $1.18^{\mathrm{a}}$ & $1.01^{\mathrm{b}}$ & 0.15 & 0.034 \\
Neck (kg) & $0.73^{\mathrm{a}}$ & $0.70^{\mathrm{a}}$ & $0.67^{\mathrm{a}}$ & $0.64^{\mathrm{a}}$ & 0.13 & 0.421 \\
Loin $(\mathrm{kg})$ & $0.70^{\mathrm{a}}$ & $0.77^{\mathrm{a}}$ & $0.67^{\mathrm{a}}$ & $0.69^{\mathrm{a}}$ & 0.14 & 0.073 \\
Leg $(\mathrm{kg})$ & $1.92^{\mathrm{ab}}$ & $1.94^{\mathrm{ab}}$ & $2.08^{\mathrm{a}}$ & $1.77^{\mathrm{b}}$ & 0.39 & 0.011 \\
Rib (kg) & $1.38^{\mathrm{a}}$ & $1.55^{\mathrm{a}}$ & $1.38^{\mathrm{a}}$ & $1.37^{\mathrm{a}}$ & 0.41 & 0.065 \\
\hline \multicolumn{7}{c}{ Yields $_{0}$ of half carcass weight) } \\
\hline Shoulder & $18.92^{\mathrm{a}}$ & $18.17^{\mathrm{a}}$ & $19.76^{\mathrm{a}}$ & $18.49^{\mathrm{a}}$ & 0.416 & 0.063 \\
Neck & $12.34^{\mathrm{a}}$ & $11.49^{\mathrm{a}}$ & $11.21^{\mathrm{a}}$ & $11.54^{\mathrm{a}}$ & 0.562 & 0.536 \\
Loin & $12.01^{\mathrm{a}}$ & $12.69^{\mathrm{a}}$ & $11.00^{\mathrm{a}}$ & $12.61^{\mathrm{a}}$ & 0.450 & 0.052 \\
Leg & $32.90^{\mathrm{ab}}$ & $32.07^{\mathrm{b}}$ & $34.85^{\mathrm{a}}$ & $32.31^{\mathrm{b}}$ & 0.617 & 0.014 \\
Rib & $23.81^{\mathrm{a}}$ & $25.56^{\mathrm{a}}$ & $23.15^{\mathrm{a}}$ & $25.03^{\mathrm{a}}$ & 0.708 & 0.087 \\
\hline
\end{tabular}

SEM: standard error of the mean. Means followed by different letters on the lines differ statistically using the Tukey test at $5 \%$ probability.

luminosity (L), red (a), and yellow (b) of the meat also did not change according to the cultivars. Likewise, forage cultivars did not affect the moisture, protein, ash, or fat content of lamb meat (Table 4).

\section{Discussion}

The lack of effect of cultivars on body weight, LWS, and the biometric characteristics evaluated in vivo and in the carcass may be related to the weight criterion chosen for slaughter (Oliveira et al., 2017; Silva et al., 2018). However, it is noteworthy that the animals that grazed in the pastures of Piatã and Massai cultivars needed about two more weeks to reach the stipulated weight for slaughter. These differences are the result of the lower nutrient intake of animals kept in the pastures of Piatã and Massai cultivars (Emerenciano et al., 2020), which resulted in a reduction in weight gain (Emerenciano et al., 2014). The time that the animal takes to reach slaughter weight must be considered when choosing a forage cultivar that will compose the production system, because the faster the animal reaches the sacrifice weight, the shorter the return time of the invested capital will be.

Although the LWS did not vary according to the cultivars, the weight of the empty body varied, and the Massai cultivar provided lower weights. This can, in part, be explained by the content of the gastrointestinal tract, which, although not significant, was superior in the animals kept in the pasture of this cultivar. This fact shows the neutral detergent fiber's ability to promote greater rumen filling and to reduce the rate of forage disappearance in the rumen (Romera et al., 2010), considering that the Massai cultivar presented higher concentrations of this fraction (Table 1).

It is likely that the highest values for empty body weight observed in animals kept in the pastures of Marandu, Piatã, and Aruana cultivars contributed to the highest HCW and CCW of these animals. However, the increase in carcass weight (hot and cold) was not enough to have an effect on their performance, as the lighter carcasses were also of animals with a lighter empty body weight. The carcass yield values are below those reported by other studies for disheveled sheep of this species finished in tropical pastures (Fernandes et al., 2013; Trindade et al., 2018), which may be associated with the supplementation of about $1.5 \%$ of the live weight used by the authors.

Little variation was observed in the yields of commercial cuts, which, in part, is justified by the body weight of the slaughtered animals and the amount of body fat: in carcasses with similar weight and amount of fat, almost all regions of the body were found in similar proportions (Trindade et al., 2018; Santos et al., 2020). However, the animals kept in the pasture of the Aruana cultivar had higher yields of ham, which, among the commercial cuts of the carcass, is the most important (Silva et al., 2016; Santos et al., 2020). This result may be a consequence of higher nutrient intakes by animals that grazed to cultivate Aruana (Emerenciano et al., 2020), which provided greater muscle development in the ham region.

The ribeye area, a parameter that corresponds to carcass muscularity, remained constant among the cultivars and is consistent with the behavior of the animals' final weight. The mean value obtained of $13.2 \mathrm{~cm}^{2}$ for the rib eye area is greater than $9.13 \mathrm{~cm}^{2}$ reported by Murta et al. (2009) and the $8.43 \mathrm{~cm}^{2}$ described by Urbano et al. (2015) in the Santa Inês sheep carcasses finished in confinement, which confirms the potential of using cultivated pastures for finishing sheep during the rainy season.

Fat deposits develop in a preferential order: first the deposition of visceral fat occurs, followed by intermuscular, subcutaneous, and finally intramuscular fat (Paulino et al., 2009). In this study, the effect of the cultivars was not significant for subcutaneous fat thickness. Furthermore, the animals deposited little fat $(0.98 \mathrm{~mm})$, a value that would not fit the carcasses in the "scarce fat" category (1-2 mm), according to the classification proposed by Silva Sobrinho (2001). Possibly, the deposition of lipids was at an early stage since this is a region of late deposit.

The non-alteration of the physico-chemical characteristics of the meat was a consequence of the little variation in the chemical 
Table 4. Physico-chemical characteristics of meat from Santa Inês lambs finished in cultivated pastures.

\begin{tabular}{|c|c|c|c|c|c|c|}
\hline Variables & Marandu & Piatã & Aruana & Massai & SEM & P-value \\
\hline $\mathrm{pH} 45 \mathrm{~min}$ & $6.25^{\mathrm{a}}$ & $6.37^{a}$ & $6.04^{\mathrm{a}}$ & $6.66^{\mathrm{a}}$ & 0.189 & 0.156 \\
\hline $\mathrm{pH} 24 \mathrm{~h}$ & $5.92^{\mathrm{a}}$ & $5.93^{\mathrm{a}}$ & $5.75^{\mathrm{a}}$ & $5.91^{\mathrm{a}}$ & 0.073 & 0.283 \\
\hline Temperature $45 \min \left({ }^{\circ} \mathrm{C}\right)$ & $32.61^{\mathrm{a}}$ & $31.78^{\mathrm{a}}$ & $33.41^{\mathrm{a}}$ & $32.12^{\mathrm{a}}$ & 0.980 & 0.662 \\
\hline Temperature $24 \mathrm{~h}\left({ }^{\circ} \mathrm{C}\right)$ & $8.30^{\mathrm{a}}$ & $10.07^{\mathrm{a}}$ & $5.22^{\mathrm{a}}$ & $8.46^{\mathrm{a}}$ & 1.260 & 0.075 \\
\hline $\mathrm{L}$ & $36.91^{\mathrm{a}}$ & $38.05^{\mathrm{a}}$ & $38.05^{\mathrm{a}}$ & $36.98^{\mathrm{a}}$ & 0.735 & 0.470 \\
\hline a & $13.81^{\mathrm{a}}$ & $13.28^{\mathrm{a}}$ & $13.28^{\mathrm{a}}$ & $13.47^{\mathrm{a}}$ & 0.529 & 0.899 \\
\hline $\mathrm{b}$ & $9.67^{a}$ & $9.20^{\mathrm{a}}$ & $9.20^{\mathrm{a}}$ & $9.54^{\mathrm{a}}$ & 0.517 & 0.931 \\
\hline Cooking losses (\%) & $33.51^{\mathrm{a}}$ & $33.63^{\mathrm{a}}$ & $33.41^{\mathrm{a}}$ & $31.42^{\mathrm{a}}$ & 0.198 & 0.614 \\
\hline Cooling losses (\%) & $4.01^{\mathrm{a}}$ & $4.73^{\mathrm{a}}$ & $4.59^{\mathrm{a}}$ & $4.88^{\mathrm{a}}$ & 0.351 & 0.360 \\
\hline Shear force $\left(\mathrm{Kgf} / \mathrm{cm}^{2}\right)$ & $2.05^{\mathrm{a}}$ & $1.91^{\mathrm{a}}$ & $2.17^{\mathrm{a}}$ & $1.88^{\mathrm{a}}$ & 0.208 & 0.746 \\
\hline Moisture (\%) & $75.19^{a}$ & $75.37^{\mathrm{a}}$ & $75.58^{\mathrm{a}}$ & $74.92^{\mathrm{a}}$ & 1.58 & 0.443 \\
\hline Ashes (\%) & $1.03^{\mathrm{a}}$ & $1.05^{\mathrm{a}}$ & $1.03^{\mathrm{a}}$ & $1.07^{\mathrm{a}}$ & 0.023 & 0.637 \\
\hline Protein (\%) & $24.42^{\mathrm{a}}$ & $23.06^{\mathrm{a}}$ & $24.37^{\mathrm{a}}$ & $23.79^{a}$ & 0.784 & 0.374 \\
\hline Fat (\%) & $2.08^{\mathrm{a}}$ & $2.60^{\mathrm{a}}$ & $1.83^{\mathrm{a}}$ & $2.09^{\mathrm{a}}$ & 0.035 & 0.246 \\
\hline
\end{tabular}

L: luminosity content of the meat; a: meat red content; b: yellow content of the meat; SEM: standard error of the mean. Means followed by equal letters in the lines differ statistically using the Tukey test at $5 \%$ probability.

composition of the cultivars. The $\mathrm{pH}$ values of the meat were within the range considered ideal for the correct establishment and resolution of rigor mortis and were close to those reported in other studies with beef sheep (Fernandes et al., 2013; Heimbach et al., 2020). Changes in $\mathrm{pH}$ was generally associated with some type of pre-slaughter stress (Li et al., 2014), with little influence from the diet to which the animal is subjected (Fernandes et al., 2013; Santos et al., 2020; Heimbach et al., 2020).

It is important to note that with the normal values of drop in the $\mathrm{pH}$ of the carcass, other quality indicators, such as water retention capacity, color, and texture, tend to be within the normal range because during the development of rigor mortis, the $\mathrm{pH}$ has a marked influence on contraction, proteolysis, and protein denaturation, resulting in changes in the structure and quality of the meat (Li et al., 2014). The values for shear force confirm that the establishment and resolution of rigor mortis occurred in an adequate way, since values below $4.6 \mathrm{kgf} / \mathrm{cm}^{2}$ indicate that the meat has an acceptable tenderness (Miller et al., 2001). Thus, it can be inferred that the lamb meat produced in pastures of Brachiaria brizantha and Panicum maximum is soft since the mean shear force was $2.00 \mathrm{kgf} / \mathrm{cm}^{2}$.

Although cooling losses have not changed due to forage, the values found were slightly higher than other studies with disheveled sheep (Urbano et al., 2015; Cardoso et al., 2016; Oliveira et al., 2017). The low layer of subcutaneous fat may be one of the causes of this finding, considering that the greater the thickness of subcutaneous fat, the lower the losses due to cooling (Cardoso et al., 2016).

\section{Conclusions}

The tropical grasses Marandu, Piatã, Aruana, and Massai can be used for finishing Santa Inês lambs in the rainy season, as they keep their physico-chemical characteristics and the centesimal composition of the meat was within acceptable standards. However, the Aruana, Piatã, and Marandu cultivars provided the highest carcass weights and ham yields.

\section{Acknowledgements}

To $\mathrm{CNPq}$ for the financial support for the development of the experiment, to CAPES and to CNPq for the granted scholarships, and to the Group of Studies on Forage (UFRN) for their assistance in implementing this work.

\section{References}

Association of Official Analytical Chemists - AOAC. (2005). Association of Official Analytical Communities. Arlington: AOAC.

Cardoso, D. M., Véras, R. M. L., Carvalho, F. F. R., Magalhães, A. L. R., Vasconcelos, G. A., Urbano, S. A., Fonsêca, G. M., \& Freitas, M. T. D. (2016). Carcass and non-carcass component characteristics of lambs fed with cassava wastewater dregs in replacement of corn. Semina: Ciências Agrárias, 37(4), 2711-2724. http://dx.doi. org/10.5433/1679-0359.2016v37n4Supl1p2711.

Duckett, S. K., Klein, T. A., Leckie, R. K., Thorngate, J. H., Busboom, J. R., \& Snowder, G. D. (1998). Effect of freezing on calpastatin activity and tenderness of callipygelamb. Journal of Animal Science, 76(7), 1869-1874. http://dx.doi.org/10.2527/1998.7671869x. PMid:9690642.

Ekiz, B., Yilmaz, A., Ozcan, M., \& Kocak, O. (2012). Effect of production system on carcass measurements and meat quality of Kivircik lambs. Meat Science, 90(2), 465-471. http://dx.doi.org/10.1016/j. meatsci.2011.09.008. PMid:21978412.

Emerenciano, J. V., No., Difante, G. S., Aguiar, E. M., Fernandes, L. S., Oliveira, H. C. B., \& Silva, M. G. T. S. (2014). Performance of meat sheep, chemical composition and structure of tropical pasture grasses managed under intermittent capacity. Bioscience Journal, 30(3), 834-842.

Emerenciano, J. V., No., Difante, G. S., Fernandes, L. S., Costa, M. G., Araujo, C. G. F., \& Luna, A. A. (2017). Avaliação econômica da produção de carne ovina em pastagens cultivadas. Custos e @ gronegócio on line, 13(1), 304-319.

Emerenciano, J. V., No., Difante, G. S., Medeiros, H. R., Aguiar, E. M., Fernandes, L. S., Trindade, T. F. M., Bezerra, M. G., Oliveira, H. C. B., \& Galvão, R. C. P. (2020). Cultivated pastures affect nutrient intake and feeding behavior of sheep. Tropical Animal Science Journal, 43(2), 117-124. http://dx.doi.org/10.5398/tasj.2020.43.2.117.

Fernandes, G. A. Jr., Lôbo, R. N. B., Madruga, M. S., Lôbo, A. M. B. O., Vieira, L. S., \& Facó, O. (2013). Genotype effect on carcass and 
meat quality of lambs finished in irrigated pastures in the semiarid Northeastern Brazil. Arquivo Brasileiro de Medicina Veterinária e Zootecnia, 65(4), 1208-1216. http://dx.doi.org/10.1590/S010209352013000400037.

Fernandes, L. S., Difante, G. S., Costa, M. G., Emerenciano, J. V. No., Araújo, I. M. M., Dantas, J. L. S., \& Gurgel, A. L. C. (2020). Pasture structure and sheep performance supplemented on diferente tropical grasses in the dry season. Revista Mexicana de Ciencias Pecuarias, 11(1), 89-101. http://dx.doi.org/10.22319/rmcp.v11i1.5083.

Folch, J., Lees, M., \& Sloane Stanley, G. H. (1957). A simple method for isolation and purification of total lipids from animal tissues. The Journal of Biological Chemistry, 226(1), 497-509. http://dx.doi. org/10.1016/S0021-9258(18)64849-5. PMid:13428781.

Gomes, R. A., Lempp, B., Jank, L., Carpejani, G. C., \& Morais, M. G. (2011). Anatomical and morphophysiological leaf blade traits of Panicum maximum genotypes. Pesquisa Agropecuária Brasileira, 46, 205-211. http://dx.doi.org/10.1590/S0100-204X2011000200013.

Heimbach, N. S., Ítavo, C. C. B. F., Ítavo, L. C. V., Difante, G. S., Dias, A. M., Brumatti, R. C., Gomes, M. N. B., Baur, C. D., de Moraes, G. J., da Costa, M. C. M., Kozerski, N. D., Leal, E. S., \& Gurgel, A. L. C. (2020). Different grass availabilities of tropical pasture on performances and carcasses of lambs. Tropical Animal Science Journal, 43(3), 211-218. https://doi.org/10.5398/tasj.2020.43.3.211.

Hopkins, D. L., \& Mortimer, S. I. (2014). Effect of genotype, gender and age on sheep meat quality and a case study illustrating integration of knowledge. Meat Science, 98(3), 544-555. https://doi.org/10.1016 /j.meatsci.2014.05.012.

Li, P., Wang, T., Mao, Y., Zhang, Y., Niu, L., Liang, R., Zhu, L., \& Luo, $\mathrm{X}$. (2014). ffect of ultimate $\mathrm{pH}$ on postmortem myofibrillar protein degradation and meat quality characteristics of chinese yellow crossbreed cattle. The Scientific World Journal, 2014, 174253. http:// dx.doi.org/10.1155/2014/174253. PMid:25197695.

Mccutcheon, S. N., Blair, H. T., \& Purchas, R. W. (1993). Body composition and organ weights in fleeceweight - selected and control Romney rams. New Zealand Journal of Agricultural Research, 36(4), 445-449. http://dx.doi.org/10.1080/00288233.1993.10417745.

Miller, M. F., Carr, M. A., Ramsey, C. B., Crockett, K. L., \& Hoover, L. C. (2001). Consumer thresholds for establishing the value of beef tenderness. Journal of Animal Science, 79(12), 3062-3068. https:// doi.org/10.2527/2001.79123062x.

Miltenburg, G. A. J., Wensing, T. H., Smulders, F. J. M., \& Breukink, H. J. (1992). Relationship between blood hemoglobin, plasma and tissue iron, muscle heme pigment, and carcass color of veal. Journal of Animal Science, 70(9), 2766-2772. https://doi.org/10.2527/1992.7092766x.

Murta, R. M., Chaves, A. M., Silva, F. V., Buteri, C. B., Fernandes, O. W. B., \& Santos, L. X. (2009). Carcass characteristics of feedlot sheep fed with sugarcane bagasse hydrolyzed with calcium oxid. Ciência Animal Brasileira, 10(2), 438-445.

Oliveira, J. P. O., Ferreira, M. A., Freitas, A. P. D., Urbano, S. A., \& Silva, A. E. M. (2017). Carcass characteristics in Santa Inês sheep fed with mazoferm as a substitution for soybean meal. Ciência Agronômica, 48(4), 708-715. http://dx.doi.org/10.5935/1806-6690.20170082.

Osório, J. C. S., Jardim, P. O. C., Pimentel, M. A., Pouey, J., Osório, M. T. M., Lüder, W. E., \& Borba, M. F. (1999). Meat production between castreded and non-castreded lambs. 1. Crossbred Hampshire Down x Corriedale. Ciência Rural, 29(1), 135-138. http://dx.doi.org/10.1590/ S0103-84781999000100024.

Paulino, P. V. R., Valadares, S. C. Fo., Detmann, E., Valadares, R. F. D., Fonseca, M. A., \& Marcondes, M. I. (2009). Deposição de tecidos e componentes químicos corporais em bovinos Nelore de diferentes classes sexuais. Revista Brasileira de Zootecnia, 38(12), 2516-2524. http://dx.doi.org/10.1590/S1516-35982009001200030.
Romera, A. J., Gregorini, P., \& Beukes, P. C. (2010). Technical note: a simple model to estimate changes in dietary composition of stripgrazed cattle during progressive pasture defoliation. Journal of Dairy Science, 93(9), 3074-3078. http://dx.doi.org/10.3168/jds.2009-2846. PMid:20630225.

Russel, A. J. F., Doney, J. M., \& Gunn, R. G. (1969). Subjective assessment of body fat in live sheep. The Journal of Agricultural Science, 72(3), 451-454. http://dx.doi.org/10.1017/S0021859600024874.

Santos, A. R. D., Souza, J. N. C., Parente, H. N., Oliveira, G. S., Rocha, K. S., Zanine, A. M., Ferreira, D. J., Lima, A. G. V. O., Araújo, J. S., Alves, A. A., \& Parente, M. O. M. (2020). Characteristics of nutrition, growth, carcass and meat of male goats fed babassu mesocarp Flour. Agriculture, 10(7), 1-13. http://dx.doi.org/10.3390/ agriculture 10070288 .

Silva Sobrinho, A. G. (2001). Aspectos quantitativos e qualitativos da produção de carne ovina. In W. R. S. Mattos, V. P. F. Faria, S. C. Silva, L. G. Nussio, \& J. C Moura (Eds.), A produção animal na visão dos brasileiros (Cap. X, pp. 425-446). Piracicaba: Fundação de Estudos Agrários Luiz de Queiroz.

Silva, F. V., Borges, I., Silva, V. L., Lana, A. M. Q., Borges, A. L. C. C., Reis, S. T., Araújo, A. R., \& Matos, A. M. (2018). Performance and carcass characteristics of lambs fed a solution of crude glycerin during feedlot and pre-slaughter lairage. Revista Brasileira de Zootecnia, 47, 1-7. http://dx.doi.org/10.1590/rbz4720170032.

Silva, P. C. G., Ítavo, C. C. B. F., Ítavo, L. C. V., Gomes, M. N. B., Feijó, G. L. D., Ferelli, K. L. S. M., Heimbach, N. S., Silva, J. A., Melo, G. K. A., \& Pereira, M. W. F. (2020). Carcass traits and meat quality of Texel lambs raised in Brachiaria pasture and feedlot systems. Animal Science Journal, 91(1), e13394. http://dx.doi.org/10.1111/ asj.13394. PMid:32538524.

Silva, T. M., Medeiros, N. A., Oliveira, R. L., Gonzaga, S. No., Queiroga, R. C. R. E., Ribeiro, R. D. X., Leão, A. G., \& Bezerra, L. R. (2016). Carcass traits and meat quality of crossbred Boer goats fed peanut cake as a substitute for soybean meal. Journal of Animal Science, 94(7), 2992-3002. https://doi.org/10.2527/jas.2016-0344.

Tilley, J. M. A., \& Terry, D. R. (1963). A two-stage technique for the in vitro digestion of forage crops. Grass and Forage Science, 18(2), 104-111. http://dx.doi.org/10.1111/j.1365-2494.1963.tb00335.x.

Trindade, T. F. M., Difante, G. S., Emerenciano, J. V. No., Fernandes, L. S., Araújo, I. M. M., Véras, E. L. L., Costa, M. G., Silva, M. G. T., \& Medeiros, M. C. (2018). Biometry and carcass characteristics of lambs supplemented in tropical grass pastures during the dry season. Bioscience Journal, 34(1), 172-179. http://dx.doi.org/10.14393/BJv34n1a2018-36781.

Urbano, S. A., Ferreira, M. A., Véras, R. M. L., Azevedo, P. S., Santos, H. B. Fo., Vasconcelos, G. A., \& Oliveira, J. P. F. (2015). Carcass characteristics and tissue composition of Santa Ines sheep fed manipueira. Revista Brasileira de Ciências Agrárias (Agrária), 10(3), 466-472. http://dx.doi.org/10.5039/agraria.v10i3a4812.

Urbano, S. A., Ferreira, M. A., Rangel, A. H. N., Lima, D. M. Jr., Andrade, R. P. X., \& Novaes, L. P. (2017). Lamb feeding strategies during the pre-weaning period in intensive meat production systems. Agroecossistemas Tropicais e Subtropicais, 20(1), 49-63.

Veras, E. L. L., Difante, G. S., Gurgel, A. L. C., Costa, C. M., Emerenciano, J. V. No., Rodrigues, J. G., Costa, A. B. G., Pereira, M. G., \& Ítavo, L. C. V. (2020). Tillering capacity of Brachiaria cultivars in the Brazilian Semi-arid region during the dry season. Tropical Animal Science Journal, 43(2), 133-140. http://dx.doi.org/10.5398/tasj.2020.43.2.133.

Weiss, W. P. (1999). Predicting energy values of feeds. Journal of Dairy Science, 76(6), 1802-1811. http://dx.doi.org/10.3168/jds.S00220302(93)77512-8. 